\title{
ASSET PRICE SHOCK RESPONSE TO SHOCK CAPITAL FLOW, EXCHANGE RATE AND INTEREST RATE: CASE STUDY OF 16 EMERGING MARKET COUNTRIES
}

\author{
Rachman Guswardi*1 \\ ${ }^{1}$ Faculty of Economics and Business, Universitas Airlangga, Indonesia
}

\section{ABSTRACT}

Capital flows to developing countries and emerging markets in the world is constantly increasing. However, the crisis that occurred in 2008 and 2011 caused concern for investors. A series of policies have been carried out in several emerging market countries to take steps prudence in controlling capital flows. This study aimed to analyze the response of asset prices to the shock caused by capital inflows, interest rates and exchange rates and analyzes the contribution of shock in capital inflows, interest rates and exchange rates on asset prices in 16 emerging market countries (India, Brazil, Russia, Indonesia, Republic of South Africa, Mexico, Thailand, South Korea, Colombia, Philippines, Egypt, Hong Kong, Peru, Czech, Bangladesh, Hungary) in the year 2001-2015. The method used is quantitative method using Panel Vector Auto Regression models. The results of this study show that the first shock of positive capital inflows will affect asset prices, both that a positive shock on interest rates will affect asset prices, the third that the positive shock of the exchange rate would affect asset prices. The variables that have the biggest contribution in influencing asset prices is the exchange rate which further interest rates and the smallest is the capital inflows
\end{abstract}

\section{ARTICLE INFO}

Received: September $25^{\text {th }}, 2016$

Revised: November $10^{\text {th }}, 2016$

Accepted: November $17^{\text {th }}, 2016$

Online: December $24^{\text {th }}, 2016$

\author{
*Correspondence: Rachman \\ Guswardi \\ E-mail: \\ rachmanguswardi@yahoo.com
}

Keywords: Capital inflows, exchange rate, interest rate, Asset Prices, Emerging Market, Panel Vector Auto Regression.

JEL: G12

To cite this document: Guswardi, R. (2016). Asset Price Shock Response to Shock Capital Flow, Exchange Rate and Interest Rate: Case Study of 16 Emerging Market Countries. JDE (Journal of Developing Economies), 1(2), 89-100

\section{Introduction}

Capital flows to developing countries and emerging markets in the world has increased significantly by $13.94 \%$ since 2000 . In particular, emerging markets in Asia and Latin America have received the impact of the capital inflows that can boost economic growth. But the subprime mortgage crisis that occurred in 2008 in the United States has made a global state facing heavy pressure. Monetary easing in developed countries and some expectation of a return on capital has a major impact on capital inflows to developing countries occurs (Allen and Carletti, 2009). The financial crisis that occurred in Europe in 2011 instead adversely affect developing countries in the form of a slowdown in economic growth significantly by $17.46 \%$. This happens due to soaring debt burden and fiscal deficit of the EU member states (Nelson et al., 2011).

The economic crisis raises concerns for investors. Owners of capital have a preference for the transfer of capital to emerging markets. Financial markets in emerging market coun-

JDE (Journal of Developing Economies) p-ISSN: 2541-1012; e-ISSN: 2528-2018 DOI: http://dx.doi.org/10.20473/jde.v1i2.3294 
tries become more attractive to the owners of capital because it offers a higher rate of return than the financial markets in developed countries. In addition, economic conditions in emerging markets are more stable also factored into the increased capital inflow.

The abundance of global liquidity after the global crisis led to increased capital flows to emerging markets. In turn, this provide a challenge for monetary policy maker. Application of extra loose monetary policy in developed countries such as quantitative easing contributes to increasing capital inflows. The policy was made to provide stimulus to the economy because in emerging markets have a higher rate of return, and supported by good economic performance (Boudias, 2015).

For emerging market countries, the increase of capital inflow can bring positive effects such as increased domestic financial liquidity, encourage investment, and promote economic growth. However, increased capital inflow should also be wary because of the risk of sudden reversal. The condition can lead to instability in the financial markets and volatility in emerging market countries. Moreover, capital inflows can also cause a rise in inflation and massive escalation of credit growth (Reinhart, 2012).

in addition to the positive impact of Capital flows, it demonstrates negative impact. First, it leads to the appreciation of the real exchange rate, weakened competitiveness in the traded goods sector. Second, the monetary policy of the central bank's tight, will cause inflation in line with the increase in asset prices sharply and the growth of credit and investment tend to be too expansive. Thirdly, can trigger and improve prolonged asset price which would then increase the financial fragility (Tillmann, 2013).

Capital flows have a force that is internationally classified as push factors and pull factors. Push factors are the financial and macroeconomic conditions in developed countries is causing investor in developed countries to invest into the market of emerging market countries. Pull factor is strongly influenced by the condition of the recipient country. This factor comes from emerging markets and is usually associated with macroeconomic conditions in a country (Calvo et al., 1996).

Basically, capital inflows to emerging markets are useful to boost economic growth. However, if a large capital flows are not managed properly, especially portfolio investment, may lead to financial risks such as boom-bust cycles that lead to crises in emerging market countries (Taguchi et al., 2015). Conditions where very high credit growth (credit boom) can improve access to the financial sector and to support investment and economic growth. But on the other side of this condition can lead to the vulnerability of the financial sector through the reduction of lending standards, as well as asset price inflation (asset bubble). This has caused concern as the financial crisis and serious economic (Reinhart and Rogoff, 2009).

A series of policies carried out in several emerging market countries since the beginning of 2009 which include South Korea, Indonesia, Thailand and Peru have taken prudence steps in controlling capital inflows mainly in capital transactions that are short term (Taguchi et al., 2015). Slowing real growth was also experienced by some Asian countries which are part of the emerging market countries include China, Indonesia, Malaysia, Thailand, Philippines and India (Guswardi, 2016).

Along with the slowdown that is characterized by reduced levels of real GDP growth, the newly industrialized countries also face the turbulent financial conditions over the last few years. Qureshi et al (2014) stated that the economic slowdown is partly due to structural bar- 
riers including the open market barriers, barriers to business operations and financial barriers to market access. Since mid-2013, there were several episodes of turmoil in financial markets, including capital outflow (capital outflow), the depreciation of the domestic currency and the decline in domestic asset prices (Pitterle et al., 2015). This gives a comparison of the current situation in 1998-1999 and raised concerns that the market crisis occurs.

Examines the relationship of capital inflows, particularly portfolio investments on asset prices. Capital inflows can directly affect demand for assets which then can affect asset prices. Research Taguchi et al (2015) aims to see the effect of capital inflows and the monetary base (M0) on stock prices in emerging markets and developing countries using a model Panel Vector Auto Regression (PVAR). The results showed a positive relationship between capital inflows in portfolio investment and the stock price, the monetary base (M0) also shown a positive impact.

The study by Sá et al (2011) and Tillmann (2013) estimated using a model Panel Vector Auto Regression (PVAR) for the OECD countries to see the response of monetary policy through interest rates and capital inflows on housing prices real home, a real credit to the private sector and housing investment. The results showed a positive relationship between capital inflow to the real price of the house, a real credit to the private sector and housing investment. An expansive monetary policy through lower interest rates are also positively related to the real price of the house, a real credit to the private sector and housing investment. In the empirical analysis there are similarities in the identification of emerging market countries and developing countries.

The purpose of this study was to examine the theoretical relationship capital inflows in portfolio investment variable specialized to asset price (stock price) in emerging market countries. The model used to estimate a model Panel Vector Auto Regression (PVAR), refers to research conducted by Taguchi et al (2015). One academic contribution of this study is the addition of the variables studied were variable interest rate and the exchange rate may affect capital inflows, such as the research conducted by Boudias (2014). Higher interest rates show the rate of return earned higher in the future. The increase in interest rates would then have an impact on the movement of capital to take advantage of higher. Olaberria (2014) in his research indicates that the interest rate has a positive effect on the level of asset prices in a country. In addition to interest rates, some studies showed that capital flows from developed to developing countries is also affected by the exchange rate.

According Siourounis (2004), Tille (2008), Ghosh and Reitz (2012), the exchange rate had a positive impact on capital inflow. The exchange rate appreciating domestic cause the value of domestic assets become more attractive because it provides a greater advantage, however, Moore and Wang (2014) show that the exchange rate had a negative relationship on capital inflows, especially in the stock market.

Investors investing in emerging markets for high returns prospects, because in emerging market countries have faster economic growth as measured by Gross Domestic Product. Investments in emerging markets have a greater risk but has a high rate of return as well. International Monetary Fund (IMF) classifies 23 countries as emerging markets, while the Morgan Stanley Capital International (MSCl) also classifies 23 countries as emerging markets, but with some differences between the two lists. Standard and Poor's (S \& P) and Russell each classifies 21 countries as emerging markets, while the Dow Jones classifies 22 countries as emerging markets. Classification of emerging market countries that are classified as emerging markets in 2016. 
This study was conducted in 16 emerging market countries that include India, Brazil, Russia, Indonesia, Republic of South Africa, Mexico, Thailand, South Korea, Colombia, the Philippines, Egypt, Hong Kong, Peru, Republic, Bangladesh, Hungary because according to GIA (Global Intelligence Alliance) the country will maintain its position as the world's top emerging market until 2017.

\section{Literature Review Model Mundell-Fleming}

The Mundell-Fleming is an open economy version of the IS-LM model that both models emphasize the interaction between the goods market and the money market. Both models emphasize that the price level is fixed and shows what causes short-term fluctuations in aggregate income. The important difference is that of the IS-LM model assumes a closed economy while the Mundell-Fleming model assumes an open economy with perfect mobility. As a result, the economy's interest rate is determined by the world interest rate (Mankiw, 2012: 356).

In the Mundell-Fleming model shown in the goods market while the IS * curve shown in the money market curve LM *. In the small open economy, the domestic interest rate may rise slightly over the short term, but the foreigners will see higher interest rate and then lend to countries offering higher interest rates.

In the interest rate in an open economy and the exchange rate becomes variable determinant in the transmission mechanism of an open economy. The increase in the money supply pressing domestic interest rates, then capital will flow out of the economy as investors seek higher investment returns. Capital outflow (capital outflow) to protect the domestic interest rate $(r)$ does not fall below the world interest rate $\left(r^{*}\right)$. In an expansive monetary policy in an open economy also had an impact on the supply increases the domestic currency in the foreign exchange market as a result of capital outflow (capital outflow). Capital outflow (capital outflow) necessitates the conversion of domestic currency into foreign currency. This causes the exchange rate to depreciate.

\section{The Exchange Rate to Asset Price}

The exchange rate will affect the return on assets when the exchange rate depreciate or appreciate. Ghosh and Reitz (2012) stated that the increase in capital inflows also affected by the exchange rate. The exchange rate affects the level of capital inflows through the price and value of domestic assets. When a currency appreciates, the domestic asset prices will be higher, causing capital flows will also increase.

\section{Capital Flows to Asset Prices}

Capital inflows can directly affect demand for assets which then can affect asset prices. Eg capital inflows in the stock market to increase demand for the stock, it will cause a rise in the stock price (Taguchi et al., 2015).

Kim and Yang (2008) says that the effect of capital inflows on asset prices through two ways: through the direct channel (rise in demand assets) and indirect channels (increase in supply). First, the portfolio capital inflows from abroad can affect demand for the assets directly. The flow of capital into the stock market led to increased demand so that the stock price increases. Furthermore, capital inflows will affect other stock markets. When the flow of capital into the stock market, the stock price will increase but the value of the rate of return will fall. This caused investors to seek higher returns in other asset markets. 
Second, capital inflows lead to a rise in the money supply and liquidity can push asset price increases. Capital inflows led to appreciation of the real exchange rate. If the monetary authorities want to avoid the appreciation of the real exchange rate is excessive then they should intervene in the foreign exchange market. Purchase of foreign currencies can be done to reduce the excess demand for domestic currency. Monetary expansion (increase in domestic interest rates) which was followed by rising capital inflows cause economic boom. The decline in foreign interest rates will also cause the income effect that will encourage the consumption boom. So that the economic boom and a consumption boom will raise asset prices. The increase in the price level (inflation) which is a result of monetary expansion also led to the rise in asset prices.

\section{Interest Rate to Assets Price}

John Maynard Keynes (1936) says that a person's level of income will affect their ability to save (Liquidity Preference Theory of interest rate). On the other hand, the decision to save is also affected by the interest rate. So, the interest rate is part of a monetary phenomenon and is determined by money supply and money demand in the aggregate (Boediono, 1985: 83).

The reasons why people used to hold money are for transactions, precaution and speculation. These three motifs are the source of the money demand on the so-called liquidity preference. Keynesian theory emphasizes the relationship between interest rates with the demand for money with the purpose of speculation. People who have excess supply of money will change the part of his wealth in the form of bank deposits or bonds that may yield a return. The interest rate is the cost opportunities between holding money or earn interest on bank deposits or bonds.

\section{Interest Rates to Capital Inflow}

Economic growth and interest rate differentials in emerging markets and developed countries is an important factor determinant of capital inflows. With the rate of economic growth and higher interest rates in emerging market countries. People will flock to invest in the form of portfolio investment compared to developed countries which tend to have high growth and low interest rates (Ahmed and Zlate, 2014).

\section{Research Method adn Models}

The model taken in this research is PVAR (Panel Vector Auto Regresion). Model PVAR (Panel Vector Auto Regresion) is formulated as follows:

$$
\left[\begin{array}{c}
S P_{i t} \\
F P I_{i t} \\
E X C_{i t} \\
I R R_{i t}
\end{array}\right]=\left[\begin{array}{l}
\beta_{0}+\sum_{j=i}^{n} \beta_{1 j} F P I_{i t-j} \sum_{j=i}^{n} \beta_{2 j} S P_{i t-j} \sum_{j=i}^{n} \beta_{3 j} E X C_{i t-j} \sum_{j=i}^{n} \beta_{4 j} I R R_{i t-j}+u_{i t} \\
\beta_{0}+\sum_{j=i}^{n} \beta_{1 j} F P I_{i t-j} \sum_{j=i}^{n} \beta_{2 j} S P_{i t-j} \sum_{j=i}^{n} \beta_{3 j} E X C_{i t-j} \sum_{j=i}^{n} \beta_{4 j} I R R_{i t-j}+u_{i t} \\
\beta_{0}+\sum_{j=i}^{n} \beta_{1 j} F P I_{i t-j} \sum_{j=i}^{n} \beta_{2 j} S P_{i t-j} \sum_{j=i}^{n} \beta_{3 j} E X C_{i t-j} \sum_{j=i}^{n} \beta_{4 j} I R R_{i t-j}+u_{i t} \\
\beta_{0}+\sum_{j=i}^{n} \beta_{1 j} F P I_{i t-j} \sum_{j=i}^{n} \beta_{2 j} S P_{i t-j} \sum_{j=i}^{n} \beta_{3 j} E X C_{i t-j} \sum_{j=i}^{n} \beta_{4 j} I R R_{i t-j}+u_{i t}
\end{array}\right]
$$

This study uses a quantitative approach with the aim of analyzing the shock of capital inflows, interest rates and the exchange rate of the response of asset prices are specialized shares in 16 emerging market countries that include India, Brazil, Russia, Indonesia, Republic 
of South Africa, Mexico, Thailand, South Korea, Colombia, the Philippines, Egypt, Hong Kong, Peru, Republic, Bangladesh, Hungary. The approach taken in this research is to use the model PVAR (Panel Vector Auto Regression).

Overall, the type of data used in this research is secondary data collected from institutions and national and international publishing in the form of data that is the panel data from 2001 to 2015. The data is derived from several sources, namely the International Monetary Fund (IMF, 2015), Quandl Financial and Economic Data (Quandl, 2015).

In order to avoid any mistakes, the meaning of the variables used in the analysis model, then the following operational definition is an explanation of the variables are used as follows: portfolio investment (FPI) obtained from equity and investment fund shares plus a portfolio of debt securities portfolio. PFI expressed as a percentage of the Gross Domestic Product of each country (domestic). Nominal Exchange Rate (EXC) is the domestic currency is determined by market exchange as the official exchange rate. The unit of the domestic currency against the US dollar. Nominal interest rate (IRR) is the interest rate set by the central bank of each country that reflects the attitude of monetary policy are taken and announced to the public. Data interest rate expressed as a percentage. Stock Price Index (SP), which includes all shares traded on the stock exchange institutions in each country. This count using a base year of 2010 .

Panel estimation Vector Autoregression (PVAR) was used to observe the effect between variables. In the model PVAR panel considers equations with fixed effects panel with the following equation:

$$
y_{i t}=A_{1} Y_{i t-1}+\ldots+A_{p} Y_{i t-p}+\eta_{i}+v_{i t},(i=1, \ldots, t=1, \ldots, T)
$$

Were $y_{i t-l^{\prime}}(l=0, \ldots, p), \eta_{i}$ and $v_{i t}$ is $\mathrm{K} \times 1$ vector, whereas $A_{j^{\prime}}(j=1, \ldots, p)$ is $\mathrm{K} \times \mathrm{K}$ the coefficient matrix. Can be written in a simple equation:

$$
y_{i t}=A X_{i t}+\mu_{i}+v_{i t}
$$

Were $A=\left(A_{1}, \ldots, A_{p}\right)$ is $K \times K \rho$ matrix, and $X_{i t}=\left(Y_{i t-1}^{\prime}, \ldots, Y_{i t-p}^{\prime}\right)^{\prime}$ is $K \rho \times 1$ vector matrix. The model can also be written as follows:

$$
x_{i t+1}=\prod x_{i t}+(d 1 \otimes \eta i)+\left(d_{1} \otimes v_{i t}\right),(i=1, \ldots, N ; t=1, \ldots, T)
$$

Were $d 1=(1,0, \ldots, 0)^{\prime}$ is $p \times 1$ vector and

$$
\prod_{K p \times K p}=\left[\begin{array}{cccc}
A_{1} & \cdots & A_{p-1} & A_{p} \\
I_{K} & & o & 0 \\
& \ddots & & \vdots \\
O & & I_{k} & o
\end{array}\right]
$$

VAR models in a simple form if written in the form of bivariate equation is as follows (Firdaus, 2011):

$$
\begin{aligned}
& y_{t}=a_{10}+a_{11} y_{t-1}+a_{12} z_{t-1}+e_{1 t} \\
& z_{t}=a_{20}+a_{21} y_{t-1}+a_{22} z_{t-1}+e_{2 t}
\end{aligned}
$$

or in the form of a matrix notation VAR are as follows:

$$
\left[\begin{array}{l}
y_{t} \\
z_{t}
\end{array}\right]=\left[\begin{array}{l}
a_{10} \\
a_{20}
\end{array}\right]+\left[\begin{array}{ll}
a_{11} & a_{12} \\
a_{21} & a_{22}
\end{array}\right]\left[\begin{array}{c}
y_{t-1} \\
z_{t-1}
\end{array}\right]+\left[\begin{array}{c}
e_{1 t} \\
e_{2 t}
\end{array}\right]
$$


In determining independent variables affect the dependent variable statistical test by using the following hypotheses:

$\mathrm{H}_{0}$ : HO not rejected if the value of Probability $>\alpha$ (Value $\alpha=1 \%, 5 \%$, or $10 \%$ ), which mean independent variable does not affect the dependent variable.

$\mathrm{H}_{1}: \mathrm{HO}$ rejected if the value of Probability $<\alpha$ (Nilai $\alpha=1 \%, 5 \%$, atau $10 \%$ ), which mean independent variables affect the dependent variable.

Impulse response function describes the level of shock variable rate of one over the other variables in a given period range. So it can be seen the length of the shock effect of a variable against another until the effect is lost or return to equilibrium.

Analysis of the impulse response function can be written in the form Vector Moving Average (VMA) of VAR equation form. VMA presented the current value and the previous value of their shock. Equations can be written, (Enders, 2014: 294):

$$
\left[\begin{array}{l}
y_{i t} \\
z_{i t}
\end{array}\right]=\left[\frac{\bar{y}}{z}\right]+\sum_{j=0}^{\infty}\left[\begin{array}{ll}
a_{11} & a_{12} \\
a_{21} & a_{22}
\end{array}\right]^{j}\left[\begin{array}{c}
e_{1 i t-j} \\
e_{2 i t-j}
\end{array}\right]
$$

Were $y_{t}$ and $z_{t}$ have a relationship with $e_{1 i t}$ and $e_{2 i t}$ sequentially. Furthermore, by using matrix algebra operations, the vector error can be determined as follows:

$$
\left[\begin{array}{l}
e_{1 i t} \\
e_{2 i t}
\end{array}\right]=\frac{1}{1-b_{12} b_{21}}\left[\begin{array}{cc}
1 & -b_{12} \\
-b_{21} & 1
\end{array}\right]\left[\begin{array}{l}
\varepsilon_{y i t} \\
\varepsilon_{y i t}
\end{array}\right]
$$

With the equations above, it can be combined into:

$$
\left[\begin{array}{l}
y_{i t} \\
z_{i t}
\end{array}\right]=\left[\frac{\bar{y}}{z}\right]+\frac{1}{1-b_{12} b_{21}} \sum_{j=0}^{\infty}\left[\begin{array}{ll}
a_{11} & a_{12} \\
a_{21} & a_{22}
\end{array}\right]^{j}\left[\begin{array}{cc}
1 & -b_{12} \\
-b_{21} & 1
\end{array}\right]\left[\begin{array}{c}
e_{1 i t-j} \\
e_{2 i t-j}
\end{array}\right]
$$

The equation can be simplified by defining the matrix $2 \times 2 \Phi_{j}$ with elements $\Phi_{k}(j)$ the same as follows:

$$
\phi_{j}=\frac{A_{1}^{j}}{1-b_{12} b_{21}}\left[\begin{array}{cc}
1 & -b_{12} \\
-b_{21} & 1
\end{array}\right]
$$

So that would be obtained form the matrix equation of impulse response function as follows:

$$
\left[\begin{array}{l}
y_{i t} \\
z_{i t}
\end{array}\right]=\left[\begin{array}{l}
\bar{y} \\
z
\end{array}\right]+\sum_{j=0}^{\infty}\left[\begin{array}{ll}
\phi_{11}(j) & \phi_{12}(j) \\
\phi_{21}(j) & \phi_{22}(j)
\end{array}\right]\left[\begin{array}{c}
e_{1 i t-j} \\
e_{2 i t-j}
\end{array}\right]
$$

Were:

$\phi_{j k}(j)$

$\phi_{j k}(0)$

$\Sigma \phi_{j k}(j)$

$\Sigma \phi_{j k}(j)$ when $n$ equals $\infty$
$=$ the effects of structural shock to the $y$ and $z$,

= impact multipliers,

= cumulative multiplayer,

$=$ long run multiplayer.

Variance decomposition also called forecast error variance decomposition is a model device in Panel VAR and VAR (time series) that separates the variation of a number of variables were estimated into components shock that provide information on the proportion of the movement of the influence of the shock at a variable to shock the other variables in the 
current period and future periods. Forecast error variance decomposition in the equation can be written as follows:

$$
Y_{i t+h}-E\left[Y_{i t+h}\right]=\sum_{1=0}^{h-1} e_{i(t+h-1)} \phi_{i}
$$

Were $Y_{i t+h}$ is the observation vector at time $\mathrm{t}+\mathrm{h}$ and $E\left[Y_{i t+h}\right]$ is the vector prediction in $\mathrm{t}$. Just as the impulse response which separates the variation of the estimated number of variables into components shock with the assumption that the variables are not mutually uncorrelated shock (Abrigo and Love, 2015).

\section{Result and Discussion}

The economic development of the countries in the world is very rapidly affected by the increased activity of the current flow of capital and trade flows of goods. That impact is due to the formation of economic integration between countries. International financial integration as well as a higher rate of return that has caused international banks and borrowers and investors to seek investment opportunities in emerging markets. Emerging markets in the study consisted of 16 countries on the continent of Asia, the Americas, Africa and in Europe. Asian continent consisting of nine countries including India, Russia, Thailand, South Korea, the Philippines, Egypt, Indonesia, Bangladesh and Hong Kong. In the Americas consists of four countries that includes Brazil, Mexico, Colombia and Peru. On the African continent include the Republic of South Africa, then in Continental Europe consists of the two countries include the Czech Republic and Hungary.

Emerging markets is a country where the economy of a country that is developing in the direction of the advanced economies. In some countries indicated increased liquidity in the debt, equity markets in the local foreign exchange market. Emerging markets cannot be considered as a developed country, however, maintains the economic and infrastructure ahead of frontier market countries (pre-emerging markets). Emerging markets have a huge potential market in the country. Investors looking for emerging markets to the prospect of high returns, because they often experience rapid economic growth as measured by Gross Domestic Product.

The driving forces of international capital flows are often classified as push factors and pull factors. Push factor due to poor global economic conditions causing investors to invest funds into emerging markets. This factor comes from low interest rates and recession (slowdown) of state investor, while the pull factors greatly influenced by the condition of the recipient country in the form of macro conditions of a country. The macroeconomic conditions such as the level of productivity, economic growth rates, and structural reforms such as financial liberalization.

Capital inflows can bring positive effects such as increased domestic financial liquidity, encourage investment, and promote economic growth for emerging markets. Nevertheless, increasing capital inflows should also be wary because of the risk of sudden reversal. The condition can lead to instability in the financial markets and volatility in emerging market countries. Moreover, capital inflows can also cause a rise in inflation and credit growth is too expansive.

Sudden reversal becomes a concern for emerging markets. Sudden reversal occurs due to the increasing instability of the exchange rate in emerging markets and the uncertainty of policy normalization conducted by the US Federal Reserve which will affect an economy emerging market countries. Quantitative easing undertaken by the United States to make 
vigilance emerging market countries in making policy. Therefore, this analysis illustrates the impact of capital inflows that are focused on portfolio investments, the nominal exchange rate, and the interest rate the central bank of each country on asset prices as seen from the stock price.

The focus of the discussion in this research is emphasized to determine the effect of portfolio investment, the exchange rate and interest rates on stock prices. Also, in this study also discusses the shock variable portfolio investment, the exchange rate and interest rates on stock prices in 16 emerging markets include India, Brazil, Russia, Indonesia, Republic of South Africa, Mexico, Thailand, South Korea, Colombia, Philippines, Egypt, Hong Kong, Peru, Republic, Bangladesh, Hungary. This study also discusses the contribution or see the variance decomposition of the investment portfolio, exchange rates and interest rates on stock prices.

Immediate response generated from the estimation PVAR used in this study indicate that the asset prices to shocks arising from variable portfolio investments showed a positive response. The increase in capital inflows to emerging markets of 16 countries will be in response to an increase in asset prices. Besides the withdrawal of capital (capital outflow), which occurred in 16 emerging market countries will result in a decline in asset prices. Taguchi et al (2015) found an increase in capital inflows in the stock market will boost stock prices, then with an increase in stock will lead to rising stock.

Results of the study demonstrated consistent with research that has been conducted by Kim and Yang (2008) that the effect of capital inflows on asset prices through two ways: through the direct channel (rise in demand assets) and indirect channels (increase in supply). First, the portfolio capital inflows from abroad can affect demand for the assets directly. The flow of capital into the stock market led to increased demand so that the stock price increases. Second, capital inflows lead to a rise in the money supply and liquidity can push asset price increases. The increase in the price level (inflation) which is a result of monetary expansion also led to the rise in asset prices. Empirically according to research conducted by (Sá et al., 2011; Tillmann, 2013; Boudias, 2015; Taguchi et al., 2015) showed that the positive effect of capital inflows on asset prices.

One of macroeconomic measurement used in the measurement of the asset price is the exchange rate. Exchange rate movements have an impact on asset prices. The results of the estimation PVAR immediate response indicates that a positive shock of the exchange rate will affect the price and value of domestic assets.

In the Mundell-Fleming model the US central bank's policy of expansion impact on increasing the money supply in the United States. After the subprime mortgage crisis that occurred in 2008, making the country the United States conducted an expansionary monetary policy to financial system stability. The increase in the money supply pressing domestic interest rates, then capital will flow out of the US economy as investors seek higher investment returns. In the expansive monetary policy in an open economy also had an impact on the supply increases the domestic currency in the foreign exchange market as a result of capital outflows. Capital outflow necessitates currency conversion United States into currencies in emerging market countries. This causes the exchange rate to depreciate the United States, while the emerging markets are experiencing exchange rate appreciation as a result of the demand for money increases.

Krugman et al (2015) states that the exchange rate will affect the return on assets when the exchange rate depreciates or appreciates. The exchange value of a country's cur- 
rency appreciation will cause the price and value of domestic assets is higher. This will lead to increased demand for domestic assets. Depreciation of the exchange rate will also result in reduced asset values. In contrast, the demand for domestic assets will be reduced when the exchange rate of the currency is depreciating. That is because the depreciation of the exchange rate of the currency causes domestic prices and asset values will be lower.

Changes in the exchange rate used to determine the return expectations of price and value of domestic assets. the return will be high when the exchange rate is expected to appreciate, while the return will be low if the exchange rate expected to depreciate. The value of asset returns can be measured on the basis of the rate of return, which is the percentage increase in the value offered for a certain period. Decisions should be based on the expected rate. In the calculation of expected returns have to make a best estimate of the value of total assets at the end of the period. The percentage difference between the expected future value and the price paid for the asset at this time is equal to the expected rate of return on assets for the period (Krugman et al., 2015).

Empirically the research results according to research conducted by Ghosh and Reitz (2013), Siourounis (2004) and Tille (2008) which shows that the exchange rate had a positive correlation with asset prices. The exchange rate affects the level of capital inflows (capital inflow) through price and the value of domestic assets. A currency appreciation will cause domestic asset prices higher.

One of the next macroeconomic measurement in the measurement of the asset price is the interest rate. The results of the estimation PVAR immediate response indicates that a positive shock on interest rates will affect the price and value of domestic assets. The interest rate is the opportunity cost between holding money or earn interest on bank deposits or bonds. People will choose to hold less money money when interest rates rise. Someone who has excess supply of money will change the part of his wealth in the form of bank deposits or bonds that can generate returns (Mankiw, 2012).

Another factor is the currency regime through changes in the money supply. Taguchi et al (2015) stated that the policy of interest rate cuts made by the United States to increase the money supply will cause investors to shift their funds to emerging market countries. The transfer of funds to emerging markets due to emerging market countries have interest rates higher than the United States.

The interest rate indicates the rate of return is received and the level of risk incurred by investors when deciding to buy equities, shares and bonds of a country. Investors would prefer to buy an investment portfolio when interest rate is high in the hope of obtaining high returns in the future. The increase in the Fed interest rate will result in the withdrawal of capital from emerging markets. Besides, the capital outflow will cause a decline in asset prices.

Mundel-Fleming model explained that the interest rate increases will cause capital to move to take higher advantage. Capital inflows to emerging markets will also lead to increase in demand of emerging market currencies. The increase in demand for emerging market currencies caused foreign investors have to buy the currency of emerging market countries to invest in the country, and with the increasing demand of money will lead to appreciation of the domestic currency.

Empirically the research results according to research conducted by Sá et al (2011) which find the monetary policy response through interest rate inflows on asset prices as mea- 
sured by the real price of the house, a real credit to the private sector and housing investment. The results showed a positive relationship between the interest rate by asset prices. Empirically also according to research conducted by Boudias (2015) and Olaberria (2014) who found that the interest rate has a positive effect on the level of stock prices in a country.

The results of the variance decomposition show that of the variable investment portfolio, exchange rates and interest rates in influencing asset prices had the biggest contribution is variable exchange rate. The contribution of the exchange rate shock on asset prices in the variance decomposition results in the amount of $0.09693 \%$. While the variable investment portfolio and interest rate have a small contribution towards the price of the asset. Contribution to the shock of the investment portfolio amounted to $0.01191 \%$, while the interest rate of $0.07508 \%$.

\section{Conclusion}

Based on the formulation of the problem and the results of analysis in the previous chapter, it can be concluded as follows:

1. Changes to capital inflows (portfolio investments) responded positively by the asset price (stock price). Changes in exchange rates also responded positively by the asset price (stock price). Changes in interest rates also responded positively by the asset price (stock price).

2. From the capital inflows (portfolio investments), exchange rates and interest rates showed that the variables that have the biggest contribution in influencing the asset price (stock price) is the exchange rate, followed by interest rates and the capital inflows (portfolio investments).

\section{References}

Abrigo, M. R., \& Love, I. (2015). Estimation of panel vector autoregression in Stata: A package of programs. manuscript, Febr 2015 available on http://paneldataconference2015. ceu. hu/Program/Michael-Abrigo. pdf.

Ahmed, S., \& Zlate, A. (2014). Capital flows to emerging market economies: a brave new world? Journal of International Money and Finance, 48, 221-248.

Allen, F., \& Carletti, E. (2009). The global financial crisis: causes and consequences. University of Pennsylvania and European University Institute.

Boediono, D. (1985). Ekonomi Moneter, Edisi 3: BPFE-Yogyakarta.

Boudias, R. (2015). Capital inflows, exchange rate regimes and credit dynamics in emerging market economies. International Economics, 143, 80-97.

Calvo, G. A., Leiderman, L., \& Reinhart, C. M. (1996). Inflows of Capital to Developing Countries in the 1990s. The Journal of Economic Perspectives, 10(2), 123-139.

Enders, W. (2014). Applied econometric time series: John Wiley \& Sons.

Firdaus, M. (2011). Aplikasi Ekonometrika Untuk Data Panel dan Time Series. Bogor (ID): IPB $\operatorname{Pr}$.

Ghosh, S., \& Reitz, S. (2012). Capital flows, financial asset prices and real financial market exchange rate: A case study for an emerging market, India (No. 461). Kiel Advanced Studies Working Papers. 
Guswardi, R. (2016). Respons Harga Aset Terhadap Shock Arus Modal Masuk, Nilai Tukar dan Suku Bunga: Studi Kasus 16 Negara Emerging Market. Surabaya Fakultas Ekonomi dan Bisnis Universitas Airlangga.

International Monetary Fund. 2015. International Financial Statistics. http://data.imf.org/.accessed April 5, 2016.

Kim, S., \& Yang, D. Y. (2008). The impact of capital inflows on emerging East Asian economies: Is too much money chasing too little good?

Krugman, P. R., Obstfeld, M., \& Melitz, M. (2015). International trade: theory and policy: Prentice Hall.

Mankiw, N. G. (2012). Macroeconomics, 8th Edition: Worth Publishers.

Moore, J., Nam, S., Suh, M., \& Tepper, A. (2013). Estimating the impacts of US LSAP's on emerging market economies' local currency bond markets (No. 595). Staff Report, Federal Reserve Bank of New York.

Nelson, R. M., Belkin, P., \& Mix, D. E. (2011). Greece's Debt Crisis: Overview, Policy Responses, and Implications. Journal of Current Issues in Finance, Business and Economics, 4(4), 371.

Olaberria, E. (2014). US Long-Term Interest Rates and Capital Flows to Emerging Economies. Journal of International Commerce, Economics and Policy, 6(02), 1550008.

Pitterle, I., Haufler, F., \& Hong, P. (2015). Assessing emerging markets' vulnerability to financial crisis. Journal of Policy Modeling, 37(3), 484-500.

Quandl. 2015. Finance and Economic Data: Share Prices Index. Tersedia dari: https://www. quandl.com/data/ accessed February 3, 2016.

Qureshi, Z., Diaz-Sanchez, J. L., \& Varoudakis, A. (2014). The post-crisis growth slowdown in emerging economies and the role of structural reforms. Global Journal of Emerging Market Economies, 7(2), 179-200.

Reinhart, C. (2012). Capital Inflows, Exchange Rate Flexibility, and Domestic Credit: University Library of Munich, Germany.

Reinhart, C. M., \& Rogoff, K. S. (2009). The aftermath of financial crises: National Bureau of Economic Research.

Sá, F., Towbin, P., \& Wieladek, T. (2011). Low interest rates and housing booms: the role of capital inflows, monetary policy and financial innovation.

Siourounis, G. (2004). Capital flows and exchange rates: An empirical analysis. London Business School IFA Working Paper(400).

Taguchi, H., Sahoo, P., \& Nataraj, G. (2015). Capital flows and asset prices: Empirical evidence from emerging and developing economies. International Economics, 141, 114.

Tille, C. (2008). Financial integration and the wealth effect of exchange rate fluctuations. Journal of International Economics, 75(2), 283-294.

Tillmann, P. (2013). Capital inflows and asset prices: Evidence from emerging Asia. Journal of Banking \& Finance, 37(3), 717-729. 